\title{
Employment Guaranteed Act: Instrument of Change in the Position of Women, A Case Study of Shopian District in J \& K State
}

\author{
Dr. Syed Damsaz Ali Andrabi \\ Social Scientist, Department of Higher Education J \& K
}

\begin{abstract}
Mahatma Gandhi National Rural Employment Guranteed Act (MGNREGA) was launched by the government of India to ensure the prosperity of rural people. In district Shopian of $\mathbf{J} \& \mathrm{~K}$, the scheme is at its full swing. The initiative has really boosted the position of women in rural areas. Before it got started their standard of living was beyond the levels of human expectations. The progressive act has opened new ways of social change. Their hidden talent got exposed and now they have their own identity in society as the earned one. Their involvement in the scheme has really shaped the destiny of family, society and nation towards new positive structural ends. But to some extent they have been discouraged by the patriarchal nature of society and have always remained at the receiving end. This is the right time to wake up, act, adopt and develop the family and society at all levels. Without your participation the target of progress cannot be achieved properly.
\end{abstract}

Keywords: Women Status, Income, Employment, Education, Self Sufficiency

\section{INTRODUCTION}

The mission of Mahatma Gandhi National Rural Employment Guranteed Act (MGNREGA), is to improve the socio-economic life of the specific group of people living in rural areas of country. In broader aspect it involves the extension of benefits and developments to the poorest sections of society especially who seek livelihood in rural areas and are without job and are also ready to do unskilled manual job provided by the government. In an advanced age poverty and unemployment continued to be the major problems faced by the people in country. Almost seventy five percent of rural population are living below standard of living. In real sense the Act (MGNREGA) has positively impacted rural population of Kashmir as well. Initially the scheme started from other parts of country, but later on it was introduced in the state of Jammu and Kashmir, including the district Shopian.

The scheme was enacted by legislation on August, 2005.A.D.It was launched on, 2, February, 2006.A.D, initially from Anantpur in Andhra Pradesh and covered two hundred poorest districts of country. The act was implemented in a phased manner .In, 20072008. A.D, one hundred thirty more districts were added to the scheme including the State of Jammu and Kashmir.

Within a span of time it spread to six hundred twenty five districts across the country. The programme has the potential to increase the economy, i. e, purchasing power of rural poor people. The scheme has really reduced the mental stress among the deprived sections and chances of migration are now very rare. The programme stipulates that all works must be targeted towards a specific set of rural developmental activities such as, rural connectivity, flood control, repair of 
embankments, water conservation, digging of new tanks, ponds, construction of small dams for public use, aforestation, others etc. The scheme provides a legal guarantee for hundred days of employment in every financial year to adult members of any rural household willing to perform public work at the statutory minimum wage of Rs. 120,(US\$2.27) per day as per, 2009,rates. The distinguishing thing is that the scheme also fosters social and gender equality as twenty three percent working workers belong to scheduled castes, seventeen percent scheduled tribes and maximum portion belong to women. The programme (MGNREAG) is designed with the following unique feature, it introduced a right based framework, legal gurantee of work, time bound action to complete the work within fifteen days incentive structure for performance, unemployment allowance to be paid within fifteen days if work is not provided, demand based resource availability and accountability of public delivery system through social audits. The said concrete Act was finally extended to State of Jammu and Kashmir on, 5, August, 2007.A. D. and its implementation is being carried out through Rural Employment guaranteed Scheme. It has been formulated on the basis of the guidelines issued by the ministry of Rural Development Government of India. In Jammu and Kashmir State the implementation of programme has been done in various phases. The auxiliary objective is strengthening of available natural resources, management through works that will address the causes of chronic poverty, draught, soil erosion and thus to encourage sustainable development of society. The marginalized and deprived sections of society have very high percentage of participation in the job oriented programme. In order to have transparency and to bring the rural people of different districts under the organised banking sector and credit system, agencies for wage payment are being separated from implementing agencies through account based wage payment. In order to benefit the workers properly the government has recently started "Ombudsman" for effective grievance redressal. The workers working under the scheme will be provided computer knowledge, literacy and financial knowledge in order to equip them with better consciousness about the projects on which they are working. The beneficial scheme was also introduced in Shopian district of Jammu and Kashmir State with an intention to provide relief to the rural people and use it as a vehicle for unique growth. As major portion of population comprised of tribals. Tribal people are among the deprived sections of society having alround backwardness, because of certain reasons, education, connectivity and superstitious beliefs. The new revenue earned sector in the area got started by the government having the five- tier, implementation starting from Central government at the top and Gram Panchayat (GP) at the bottom .

Central government comes at the top of hierarchy and ministry of Rural Development, New Delhi is the nodal agency of programme. The concerned agency has the full responsibility to set up central employment gurantee council for receiving advices on implementation of (MGNREGA) programme. Besides above it has to evaluate, monitor and disburse funds according to budget allocation. State government acts as a facilitator in flow of funds and helping in preparation of manpower, evaluation and supervision of duties. District Panchayat coordinates activities and also has the responsibility of preparing district annual and five yearly perspective plans. These two plan documents are the very basics which will guide how to implement the programme at village level. Both of them are prepared at district level in consultation with Gram Panchayat. Block Panchayat monitors and coordinates the plan and works at block level. Updating of records, muster roll entries are done at the block level under the guidance of programme officer and Gram Panchayat is the nodal agency at the bottom level. Gram Panchayat has the authority to select, design and to complete the alloted works. Supervision, monitoring and selection of works are done by the concerned Gram authority. They have the authority to receive the applications for employment, registration of households, issuance of job cards etc. If utilized properly the scheme can raise the status of tribal women. Among them is found the all-round backwardness because of their isolation from the rest of society. They are illiterate, superstitious and orthodox. All these measures together contributed a lot towards their deplorable life. The progressive programmes like, education and connectivity are distant dreams for them. Literacy rate among the tribal people of Shopian at present is, 15.4 per cent while as among others it is, 66.21 per cent .The need of the hour is to change the position of women through the employment Guranteed Act started by the government as they are lagging behind due to illiteracy which makes them narrow minded.

Their very position in the Shopian district is very miserable and painful. Females are begging from door to door for survival and their position is beyond the 
levels of human expectations. The education for them is a distant dream. The biggest obstacle in the way of education is the early marriage. Normally 80 percent parents prefer early marriage of their sons and daughters. The marriageable age of males is between the age group of, 15 to 20 years and among females is between, 12 to 18 years only while as among others it is between, 30 to 35 years of age. So the ultimate responsibility for moulding their climate of opinion in favour of new innovation (MGNREGA) lies with the administration as well as educational research cumextension institutional programmes supervised by experts. Under such circumstances the Guranteed Act will act as a deciding factor to change the status of women in rural areas of Shopian. The Act is the most progressive legislations enacted in area since its inception. It is a bold and unique policy in the provisions of employment in the areas. While women force has always been an essential component in the functioning of their household duties. By providing them cash earnings scheme has both increased and diversified the contributions that women are making to household income as wages earner. Women participation is at its increasing scale in the work activities of employment programme. Their changing income has accelerated the demand of work and the agencies have to think over it. Nevertheless the overall impact of programme on women is quite positive in many ways, whether it is increased income, independence, self confidence and contribution to food security. The role of Act as a tool of women empowerment deserves much more attention than it has received so far. In real there are visible changes in behavior and attitude of women. Their participation in the works has ensured effective participation both as workers and also as administrators. Because of the programme women are having their own identity as workers, farmers and cultivators. Also created a development interface for women to participate in different developmental programmes. The money earned through the guaranteed Act is utilized by them to remove their domestic sufferings. Majority of the women are completely illiterate, but they have managed to work to free themselves from the clutches of poverty. Because of the educational deficiency their condition is really deplorable. But the scheme provided them an opportunity of development. Among the novel methods of scheme one member of each family living below poverty line would be given a job. There are also thirty three percent reservations for women and exceptionally it may be increased up to forty percent.
By providing them the better options the bargaining power of rural women workers will be increased to a greater extent.

In order to make the life of women self-sustaining the mission of scheme is the overall structural change in the socio-economic condition of women and also to improve the living standard of low income population residing in far flung rural areas of Shopian. The act has really ensured the participation of women in different projects. By giving them cash money or by way of transfer has increased their interest in the work. The money has changed the traditional system of their domestic life. Both qualitative and quantitative social impact assessments suggest that women workers are more confident about their role as contributors to family expenditure. They are also becoming more assertive about their space in public sphere. The beneficiaries are satisfied that the scheme has really brought a considerable change in their life, families as well as in villages. This is also because the employment is provided to them in their own locality. Generating community assets have enhanced their spending capacity. However most of the women workers felt that the Act created an equal opportunity of work. The guranteed income may be small but assured her social status. Almost seventy two percent workers said that they spend earned money on routine food and consumer goods. The increased income helped them to take two time meals at least. As such the amount is insufficient but to some extent has solved the day today problems. Nevertheless twenty eight percent workers used to spend their money on education of their children. Besides the basic necessities their health standard has got completely improved. Because of availability of money they are in a position to purchase the medicine for themselves otherwise it was dead impossible for them. The employment scheme has really generated awareness among the females and now they begin to take part in Panchayat Raj Institution (PRIS) and Gram Sabha. The scheme is designed in such a way that fifty percent of all the sanctioned works are to be implemented through Gram Panchayats and Panchayat Raj Institutions (PRIS) . The Gram Sabha (village committee) too plays a crucial role in the selection of works and the conduct of social audits. Their participation in these institutions is the potential act. Numbers of them at present are acting as Punchs and Sir Punchs in different rural areas of district Shopian. No doubt their participation is very less but still there is much scope to increase their involvement 
in Panchayat Raj Institutions. So that their long pending demands can be solved to a greater extent. Empowerment can be provided to them through different steps beginning with welfare, access to resources, awareness and active participation in social activities. Lastly women empowerment can be achieved when menfolk will liberate themselves from the false value systems, ideologies of oppressions to the extent where everyone can become equal irrespective of gender and all will use their fullest potential and will work to build actual humane society for all.

\section{CONCLUSION}

The programme of guaranteed employment Act has completely opened new avenues of earning for the women. Backwardness, illiteracy and orthodoxy to a larger extent got removed from the families of women workers. The women are now having their own identity in society. Their hidden talent got exposed and they proved best workers and administrators.The act provided them the concept of equality in economic terms.In real sense there was emancipation among them from the old strings that has ultimately brought revolutionary changes in the overall setup of society.

\section{REFERENCES}

1) Abdul Aziz and Rao V, M,Poverty alleviation in India, Delhi, 1989.

2) Ahmad P. M, Integral rural development progeamme in Kashmir division, reconciliation between theoretical constructs and empirical magnitudes.

3) Bagchee Aruna, Political and administrative realities of employment gurantee scheme, economic and political weekly, vol, 40(42),2005.

4) Arun Jacob, Richard Varghese, NREGA implementation, reasonable, 2006.

5) Ambasta Vijaj Shankar and M. Shah, Two years if NREGA, the road ahead, economic and political weekly, vol, 43.no.8.2008.

6) Mathur , Yojna A Developmental Magazine August, 2008, Article on Fulfilling the Promise.

7) Singh R. P,Yojna A Developmental Magazine, August 2008

8) Center for research in rural and industrial development, Appraisal /impact assessment of NREGAS in selected districts of Kashmir (Shopian, Pulwama, Kulgam and Anantnag)Report submitted to ministry of rural development,2009.
9) Bedi and etal, The national rural development guarantee scheme in birbhum, economic and political weekly, vol, 65,2010.

10) Adhikari and Kartika, NREGA wage payments, economic and political weekly, vol, 45,2010.

11) Bhatia and Adhikari, NREGA wage payments, can we bank on the banks, economic and political weekly, vol, 65,no.1\&2,2010.

12) Babu S H. Rao, P. T. Reddy and D. Chakrabarty, Impact of MGNREGA on agriculture and rural labour markets, a study of Kashmir Institute of rural development, 2011.

13) Mannual of NREGS-JK scheme.

14) Berg, E. S Bhatachariya, R, Durg and Ramachandra, Can rural public works affect agriculture wages, evidence from India, wps/2012-5,oxford,center for study of African economics working papers, 2012.

15) Aiyar, Yamini and Salimah Samji, Improving the effectiveness of National Rural Employment Gurantee Act, Economic and political weekly, vol, 41,(4).2012.

16) Ajaj Kumar Singh Niti Sury and Sameer Lama, MGNREGA, a critical assessment of issues and challenges, the Indian journal of commerce, vol, 65,2012.

17) J\&K Department of Rural Development Kashmir "Targets and Achievements" through Quarterly Magazine "Dehat Sudhar" Issue June 2013.

18) India Ministry of Rural Development, The National Rural Employment Guarantee Act 2005 (MGNREGA): Operational guidelines 4th Edition 2013.

19) Pal M, Kurukshetra A Journal on Rural Development, October 2014 . 